\title{
Forage Value of Invasive Species to the Diet of Rocky Mountain Elk
}

\author{
By Michel T. Kohl, Mark Hebblewhite, Shawn M. Cleveland, and Ragan M. Callaway
}

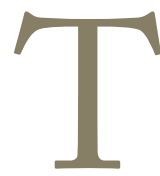

he winter range of Rocky Mountain elk (Cervus canadensis) throughout the Intermountain West is threatened by invasive plant species including spotted knapweed (Centaurea maculosa) and cheatgrass (Bromus tectorum). These species have direct impacts on pasture and grasslands resulting in substantial forage losses and costs associated with prevention and mitigation. Invasive species cost the United States $\$ 120$ billion annually, with knapweed estimated to cost $\$ 14$ million annually to the economy of Montana. ${ }^{1}$ Knapweed and cheatgrass are aggressive invaders, and are generally more common in disturbed sites resulting from overgrazing, fire, cultivation, or other forms of ground disturbance, but can invade and transform relatively undisturbed rangeland. ${ }^{2,3}$ The biochemical and physiological characteristics of knapweed allow it to outcompete native plants through greater resource acquisition and inhibition of native plant growth and seed germination. ${ }^{4}$ Similarly, cheatgrass may inhibit native grass germination by rapidly outcompeting natives for soil moisture and nitrogen ${ }^{6}$ and increase fine dry fuels leading to increased fire intervals that favor cheatgrass dominance. ${ }^{7}$

Due to the transformation of native grasslands to systems dominated by invasive species, numerous studies have examined the forage value of knapweed and cheatgrass for domestic livestock and reported these exotic plants may have substantial value at specific times of the year. For example, the nutrient content (crude protein: 6.2-18.2\%) of knapweed during its succulent state in western Montana is comparable to or higher than that of native plants and meets the requirements of livestock. ${ }^{8}$ However, the chemical cnicin in the leaves of knapweed decreases palatability after flowering, and decreasing nutrient content with age results in an overall reduction in forage quality. ${ }^{9}$ Cheatgrass is also a forage resource for livestock, primarily during spring and winter. Cheatgrass is capable of withstanding repeated grazing; however, its forage value dramatically decreases as the plant cures throughout the summer season. ${ }^{5}$

In addition to the effects of these weeds on livestock forage, they pose important issues for wildlife managers due to a reduction in native grasses and winter range carrying capacity that can displace economically and socially important wildlife. These ecological concerns have led to a variety of methods to reduce knapweed and cheatgrass biomass. Knapweed control methods include biocontrol agents, manual removal, domestic sheep (Ovis aries) grazing, and broadcast herbicide application. Cheatgrass control methods include domestic livestock grazing, herbicide application, and combinations of herbicide and reseeding.

Although there has been extensive research on the control and eradication of exotic plants, we do not fully understand these control and eradication efforts in the context of wildlife effects and responses. Tyser and Key ${ }^{10}$ proposed that ungulates may selectively feed on native species, reducing the native's ability to compete with exotics present within the plant community. There is other evidence that knapweed is not a preferred forage source and is only consumed at high ungulate densities or in areas of extremely high knapweed cover. ${ }^{11}$ Likewise, herbivores may also avoid the use of cheatgrass as forage because of its limited nutrient quality when it is not in the vegetative state. Our objective was to test whether Rocky Mountain elk used invasive species on their winter range, areas of high conservation value that are experiencing high rates of invasion by cheatgrass and spotted knapweed. We predicted elk would use invasive species, albeit at minimal levels, due to accidental use in invaded grasslands and when use occurs during the limited periods in which these invasives provide adequate nutritional value.

\section{Our Study Areas}

We chose five elk populations from western Montana to test for the presence of invasive species in their diet (Fig. 1; Photo 1). Site 1 was located $61 \mathrm{~km}$ northeast of Missoula, Montana, at the Blackfoot-Clearwater Game Range (lat $47^{\circ} 5^{\prime} 38^{\prime \prime} \mathrm{N}$, long $113^{\circ} 22^{\prime} 37^{\prime \prime} \mathrm{W}$ ), where approximately 1,000 elk winter on montane grasslands with low infestation levels and minimal herbicide application areas. Site 2, North Hills winter range (lat $46^{\circ} 53^{\prime} 45^{\prime \prime} \mathrm{N}$, long $114^{\circ} 2^{\prime} 31^{\prime \prime} \mathrm{W}$ ), and site 3, Mount Jumbo Open Space Park (lat 46 $53^{\prime} 45^{\prime \prime} \mathrm{N}$, long $113^{\circ} 56^{\prime} 31^{\prime \prime} \mathrm{W}$ ), consist of two elk populations (approximately 300 and 100 elk, respectively) located north of Missoula in an area supporting varying levels of exotic plants and large tracts of herbicide application areas using Tordon (1-2 pints per acre) or Milestone (5 ounces per acre). Sites 4 and 5 were located at the Threemile (lat $46^{\circ} 35^{\prime} 24^{\prime \prime} \mathrm{N}$, long $113^{\circ} 53^{\prime} 27^{\prime \prime} \mathrm{W}$ ) and Calf Creek (lat $46^{\circ} 16^{\prime} 40^{\prime \prime} \mathrm{N}$, long $\left.113^{\circ} 58^{\prime} 48^{\prime \prime} \mathrm{W}\right)$ wildlife management areas located 48 and $64 \mathrm{~km}$ south of Missoula, respectively. Sites 4 and 5 supported approximately 45 and 200 elk, respectively. Both sites 


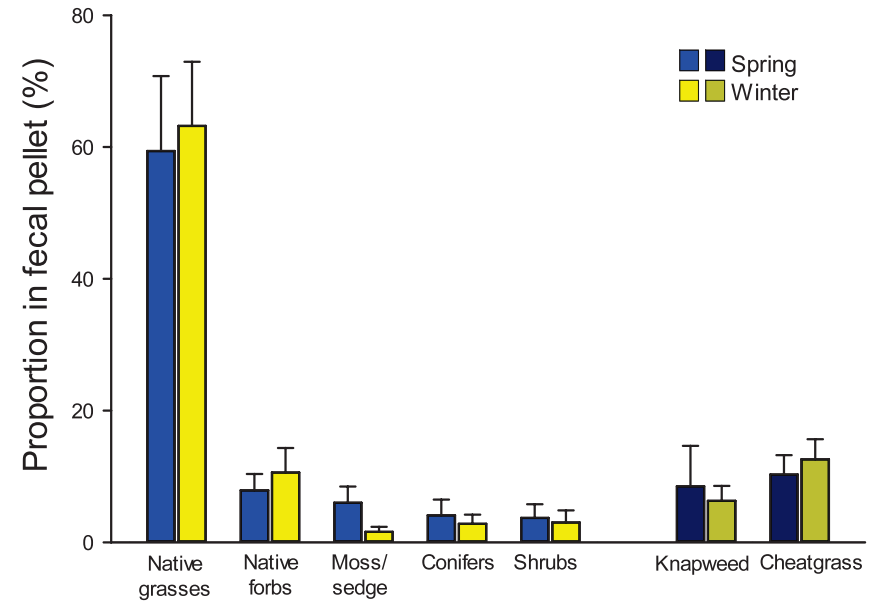

Figure 1. Mean proportional dietary use of different taxonomic groups by elk as determined by fecal pellet analysis averaged for five populations in western Montana in the spring and winter of 2008. Error bars represent 1 standard error. Based on one-way analysis of variance there were no differences between seasons for any vegetation group.

support higher levels of weed infestation and are treated with both biocontrol and herbicide application (Milestone: 6 ounces per acre). Plant communities were similar across all study areas, generally consisting of ponderosa pine (Pinus ponderosa) and mixed bunchgrass communities dominated by native grasses including bluebunch wheatgrass (Agropyron spicatum), Idaho fescue (Festuca idahoensis), green needlegrass (Stipa viridula), and needle-and-thread grass (Stipa comate). Dominant forbs include arrowleaf balsamroot (Balsamorhiza sagittata) and lupine (Lupinus spp.). Invasive plant species include cheatgrass, knapweed, sulfur cinquefoil (Potentilla recta), and leafy spurge (Euphorbia esula).

\section{Fecal Samples}

We collected pellet samples from elk rectums during the handling of 12 adult females for a related study (Photo 2)

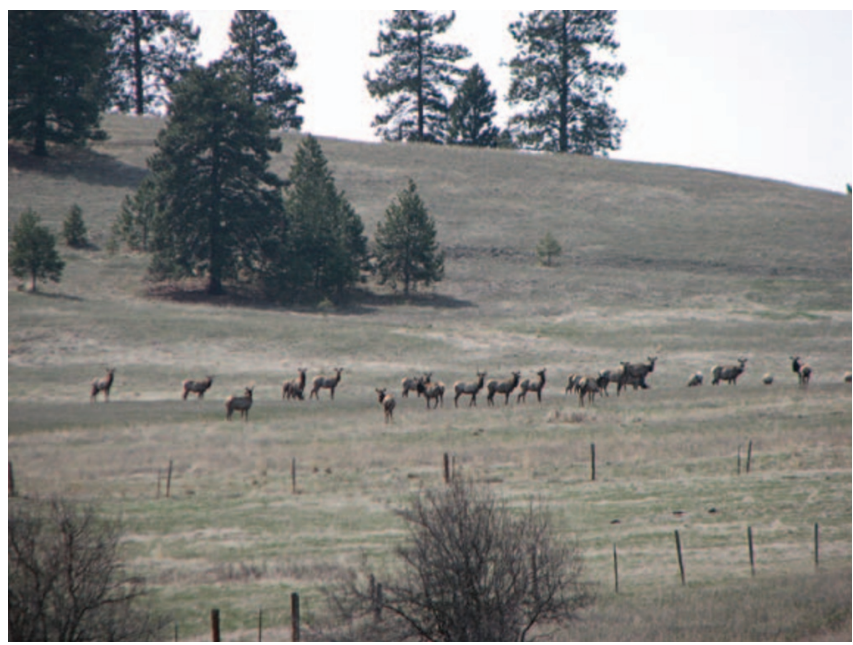

Photo 1. Rocky Mountain elk populations were located in ponderosa pine-mixed bunchgrass communities with varying levels of invasive species. Photo credit: Michel Kohl.

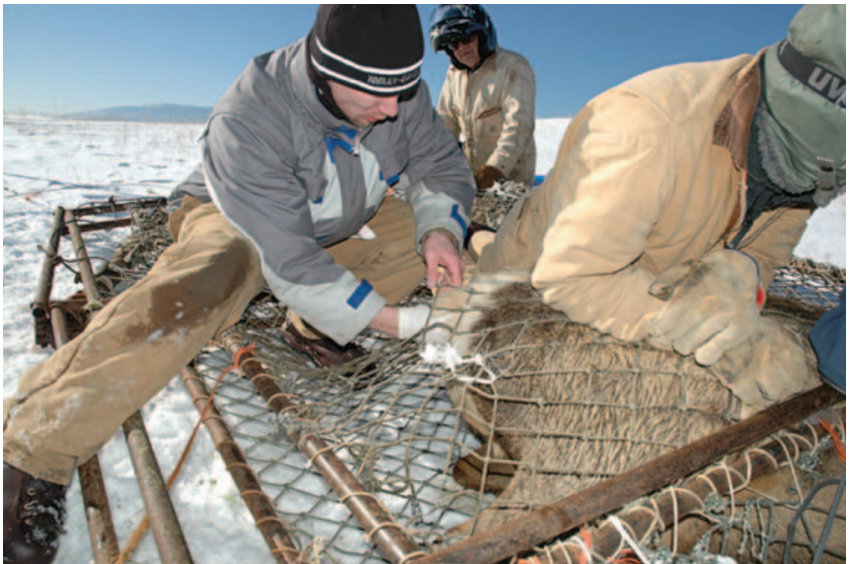

Photo 2. Collection of fecal samples during handling of adult cow elk. Photo credit: Jean Polfus.

or from the field on open prairie flats (Photo 3) from February to June (Table 1). Each sample constituted a composite of two individual pellets selected from 20 pellet groups; this was a sample size of composite samples similar to a previous study, which examined the comparative diet content of ungulates. ${ }^{12}$ Pellet groups were located $\leq 100 \mathrm{~m}$ from vegetation plots and were separated by $>1 \mathrm{~m}$ to provide a representation of population diet. We separated samples seasonally into winter

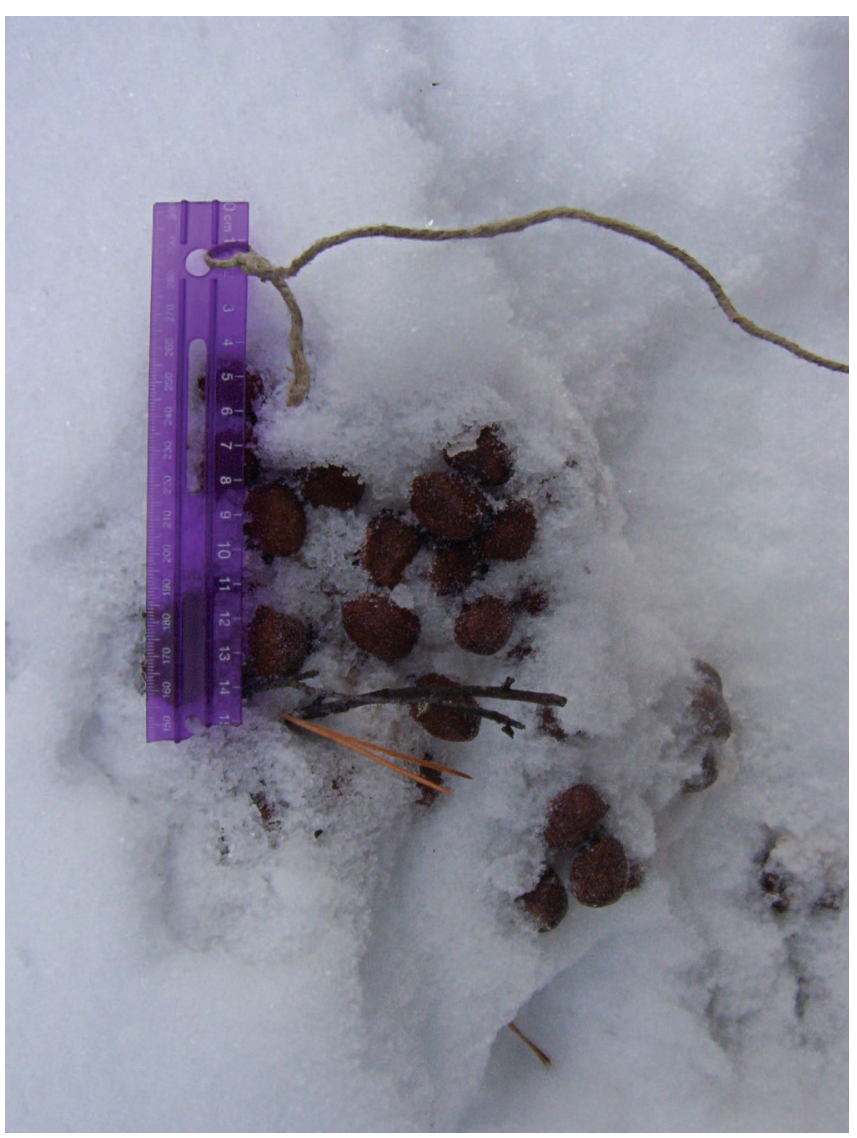

Photo 3. A fecal sample used to make composite diet samples of elk populations. Photo credit: Mark Hebblewhite. 


\begin{tabular}{|c|c|c|c|c|}
\hline \multirow[b]{2}{*}{ Forage season } & \multicolumn{2}{|c|}{ Collection } & \multicolumn{2}{|c|}{ Sample size } \\
\hline & Season & Technique & Individuals & Composites \\
\hline \multicolumn{5}{|l|}{ BCGR } \\
\hline Winter & Spring & Prairie & 40 & 2 \\
\hline Spring & Spring & Prairie & 40 & 2 \\
\hline \multicolumn{5}{|l|}{ North Hills } \\
\hline Winter & Winter & Rectum & $32 *$ & 2 \\
\hline Spring & Spring & Prairie & 40 & 2 \\
\hline \multicolumn{5}{|l|}{ Mt. Jumbo } \\
\hline Winter & Winter & Prairie & 20 & 1 \\
\hline Spring & Spring & Prairie & 20 & 1 \\
\hline \multicolumn{5}{|l|}{ Threemile } \\
\hline Winter & Winter & Prairie & 20 & 1 \\
\hline Spring & Spring & Prairie & 20 & 1 \\
\hline \multicolumn{5}{|l|}{ Calf Creek } \\
\hline Winter & Winter & Prairie & 20 & 1 \\
\hline Spring & Spring & Prairie & 20 & 1 \\
\hline
\end{tabular}

(1 January-31 March) and spring (1 April-30 June). Samples collected at sites 1,4 , and 5 were collected during late spring and were designated to winter or spring based on visual appearance. Within each vegetation plot, we performed a visual estimate of species cover to provide a measure of forage availability. Washington State University Wildlife Nutrition Laboratory (Pullman, WA, USA) analyzed the dietary content using fecal plant fragment (diet hereafter) analysis to genus level. We used a one-way analysis of variance to test for differences between diet components across populations and seasons.

\section{Use of Invasives by Elk}

There were no differences in the quantities of any vegetation classes in elk fecal pellets across seasons, in fact the analysis showed nearly identical use of different plant classes in winter and spring (Table 2). Native grasses composed 63.2\% and $59.4 \%$ of the diet in winter and spring, respectively; however, there were differences in native grass use among

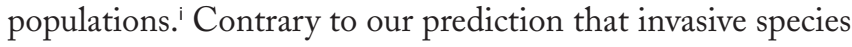
would compose very little of elk diets, invasives composed a sizeable percentage of the diet in winter (18.9\%) and spring (18.8\%). Across all the elk populations, knapweed averaged $6.3 \%$ and $8.5 \%$ of elk diet during winter and spring, respectively, and cheatgrass averaged $12.6 \%$ and $10.3 \%$ of their diet for winter and spring, respectively. The dietary use of invasives varied among populations for spring knapweed use $^{\mathrm{ii}}$ and there was a large range in the seasonal use of knapweed among populations. In winter, knapweed in fecal pellets ranged from $0 \%$ to $15 \%$ among populations, and from $0 \%$ to $47 \%$ among populations in the spring. Cheatgrass showed similar winter and spring use ranging from $0 \%$ to $21 \%$ and from $2 \%$ to $23 \%$, respectively, in fecal pellets (Table 1 ).

\section{Management Implications}

We predicted elk would consume minimal levels of invasive species; however, our dietary analysis provides evidence these species may be important components of elk diet during winter and spring, particularly under certain conditions. Previous nonquantitative observations at sites 4 and 5 indicated elk consumed knapweed at low levels ${ }^{13}$ however, for this particular site we found knapweed consisted of $14.6 \%$ (winter) and $47.1 \%$ (spring) of the diet, levels much higher than previously reported in the literature. Conversely, this level of consumption was several times higher than any other population we measured, and when excluding this exceptionally high level the mean proportion of knapweed in fecal pellets across all elk populations was only $4.8 \%$. 
Table 2. Fecal plant fragment analysis data for dietary content from five elk populations. Two fecal composite samples were taken from BCGR and North Hills populations, thus average and high values are provided

\begin{tabular}{|c|c|c|c|c|c|c|c|c|}
\hline Elk population & $\begin{array}{c}\text { Native } \\
\text { forbs } \%\end{array}$ & $\begin{array}{c}\text { Knapweed } \\
\%\end{array}$ & $\begin{array}{c}\text { Native } \\
\text { grass } \%\end{array}$ & $\begin{array}{c}\text { Cheatgrass } \\
\%\end{array}$ & $\begin{array}{c}\text { Moss/ } \\
\text { Sedge } \%\end{array}$ & Conifer \% & Shrub \% & TOTAL \% \\
\hline BCGR & & & & & & \\
\hline Spring average & 1.60 & 0.00 & 68.75 & 13.65 & 7.45 & 7.50 & 1.05 & 100.00 \\
\hline Spring high & 2.70 & 0.00 & 79.40 & 23.00 & 14.90 & 13.70 & 2.10 & \\
\hline Winter average & 4.35 & 2.65 & 78.25 & 10.20 & 0.85 & 0.00 & 3.70 & 100.00 \\
\hline Winter high & 5.30 & 5.30 & 82.80 & 11.20 & 1.70 & 0.00 & 6.50 & \\
\hline North Hills & & & & & & & \\
\hline Spring average & 8.60 & 3.45 & 64.50 & 8.85 & 9.55 & 0.00 & 5.05 & 100.00 \\
\hline Spring high & 10.20 & 6.90 & 67.20 & 15.50 & 15.70 & 0.00 & 10.10 & \\
\hline Winter average & 10.95 & 3.40 & 63.00 & 15.20 & 4.25 & 3.20 & 0.00 & 100.00 \\
\hline Winter high & 13.50 & 3.60 & 68.40 & 19.90 & 5.40 & 6.40 & 0.00 & \\
\hline Threemile & & & & & & & \\
\hline Spring & 13.70 & 47.10 & 13.70 & 11.80 & 0.00 & 0.00 & 13.70 & 100.00 \\
\hline Winter & 5.90 & 14.60 & 39.70 & 15.90 & 1.30 & 9.30 & 13.30 & 100.00 \\
\hline Mt. Jumbo & & & & & & & \\
\hline Spring & 18.10 & 4.20 & 47.20 & 11.10 & 5.50 & 13.90 & 0.00 & 100.00 \\
\hline Winter & 31.70 & 15.00 & 53.30 & 0.00 & 0.00 & 0.00 & 0.00 & 100.00 \\
\hline Calf Creek & & & & & & & \\
\hline Spring & 3.40 & 1.10 & 88.70 & 4.50 & 2.30 & 0.00 & 0.00 & 100.00 \\
\hline Winter & 5.70 & 2.50 & 66.60 & 21.40 & 0.00 & 3.80 & 0.00 & 100.00 \\
\hline BCGR indicates Blackfoot-Clearwater Game Range. & & & & \\
\hline
\end{tabular}

Likewise, in previous studies, the dietary use of cheatgrass appears to be relatively low $(5 \%)^{14}$ or used only in early spring when the plant is high in nutritional quality. ${ }^{15}$ Although cheatgrass is consumed by other ungulates such as mule deer (Odocoileus hemionus) and bighorn sheep (Ovis canadensis), our study is the first to report significant levels of cheatgrass use (21.4\%) by elk.

These results have significant implications for wildlife and range managers trying to protect critical winter range for species such as Rocky Mountain elk. First, the demonstration that elk will use these areas despite the occurrence of exotic plant species indicates the potential for increased ground disturbance through elk grazing and trampling actions. In areas on the verge of invasion or that have been recently treated, this may lead to increased invasion rates by exotics. Second, the habitat use of these areas and dietary use of these species may result in seed transmission via fur or feces to intact grasslands or adjacent summer ranges. As a result, our study leads to economic questions regarding the proper management of winter ranges already supporting invasive species. In areas that support migrating ungulates on invaded grasslands, managers should be aware of the possibility of fecal transmission to adjacent grassland systems, implement monitoring protocols, and use approved control methods (i.e., herbicide, grazing, fire) to prohibit further expansion.

\section{Acknowledgments}

The authors wish to thank the private landowners who provided access to their properties. The authors would also like to thank Dr Paul R. Krausman and two anonymous reviewers for their valuable editorial comments.

\section{References}

1. Hirsch, S. A., And J. A. Leitch. 1996. The impact of knapweed on Montana's economy. Fargo, ND, USA: North Dakota State University, Agricultural Experiment Station. Agricultural Economics Report 355.43 p.

2. Ridenour, W. M., and R. M. Callaway. 2001. The relative importance of allelopathy in interference: the effects of 
an invasive weed on a native bunchgrass. Oecologia 126: 444-450.

3. Ortega, Y. K., and D. E. Pearson. 2011. Long-term effects of weed control with picloram along a gradient of spotted knapweed invasion. Rangeland Ecology \& Management 64:6777.

4. Kelsey, R. G., and L. J. Locken. 1987. Phytotoxic properties of cnicin, a sequiterpene lactone from Centaurea maculosa (spotted knapweed). Journal of Chemical Ecology 13:19-33.

5. Young, J. A., And F. L. Allen. 1997. Cheatgrass and range science: 1930-1950. Journal of Range Management 50:530-535.

6. Besaw, L. M., G. C. Thelen, S. Sutherland, K. Metlen, and R. M. Callaway. 2011. Disturbance, resource pulses and invasion: short-term shifts in competitive effects, not growth responses, favour exotic annuals. Journal of Applied Ecology 48:998-1006. doi:10.1111/j.1365-2664.2011.01988.x

7. Getz, H. L., and W. L. Baker. 2008. Initial invasion of cheatgrass (Bromus tectorum) into burned pinon-juniper woodlands in western Colorado. American Midland Naturalist 159:489-497.

8. Kelsey, R. G., and R. D. Mihalovich. 1987. Nutrient composition of spotted knapweed (Centaurea maculosa). Journal of Range Management 40:277-281.

9. Watson, A. K., and A. J. Renny. 1974. The biology of Canadian weeds. 6. Cenaturea diffusa and C. maculosa. Canadian Journal of Plant Science 54:687-701.

10. Tyser, R. W., and C. H. Key. 1988. Spotted knapweed in natural area fescue grasslands: an ecological assessment. Northwest Science 62:151-160.

11. Wright, A. L., and R. G. Kelsey. 1997. Effects of spotted knapweed on cervid winter-spring range in Idaho. Journal of Range Management 50:487-496.
12. Hebblewhite, M., E. Merrill, and Greg McDermid. 2008. A multi-scale test of the forage maturation hypothesis in a partially migratory ungulate population. Ecological Monographs 78:141-166.

13. Lavelle, D. A. 1986. Use and preference of spotted knapweed (Centaurea maculosa) by elk (Cervus elaphus) and mule deer (Odocoileus hemionus) on two winter ranges in western Montana [thesis]. Missoula, MT, USA: University of Montana. 72 p.

14. McCorquodale, S. M. 1993. Winter foraging behavior of elk in the shrub-steppe of Washington. Journal of Wildlife Management 57:881-890.

15. Buechner, H. K. 1952. Winter-range utilization by elk and mule deer in southeast Washington. Journal of Range Management 5:76-80.

Authors are Undergraduate Student, Wildlife Biology Program, 32 Campus Dr, University of Montana, Missoula, MT 59812, USA, michel.kobl@umontana.edu (Kobl); Associate Professor of Ungulate Habitat Ecology, Wildlife Biology Program, 32 Campus Dr, University of Montana, Missoula, MT 59812, USA (Hebblewhite); Graduate Student, Wildlife Biology Program, 32 Campus Dr, University of Montana, Missoula, MT 59812, USA (Cleveland); and Professor of Plant Ecology, Division of Biological Sciences, University of Montana, 32 Campus Dr, Missoula, MT 59812, USA (Callaway). Funding was provided by Montana Fish, Wildlife, छ Parks, Rocky Mountain Elk Foundation, Montana Integrative Learning Experience for Students, and the Irene Evers' Undergraduate Research Program. 